\title{
Comparison of Seed Bank Estimation Techniques Using Six Weed Species in Two Soil Types
}

\author{
Erin K. Espeland, ${ }^{1}$ Lora B. Perkins, ${ }^{2}$ and Elizabeth A. Leger ${ }^{3}$
}

Authors are ${ }^{1}$ Research Ecologist, US Department of Agriculture-Agricultural Research Service, Northern Plains Agricultural Research Laboratory, 1500 N Central Ave, Sidney, MT 59270, USA; and ${ }^{2}$ Graduate Student and ${ }^{3}$ Assistant Professor, Department of Natural Resources, University of Nevada, Reno, Reno, NV 89557, USA.

\begin{abstract}
Evaluation of the viable seeds in a soil, otherwise known as the seed pool or seed bank, is a crucial component of many weed dynamic and plant ecology studies. Seed bank estimation is used to predict the possibility of future weed infestations in rangelands as well as the nascent native plant diversity within them. However, there is no standardized method of reporting seed bank evaluation techniques, limiting the ability to compare across studies. After sowing known quantities of cheatgrass, Bromus tectorum (L.); brome fescue, Vulpia bromoides (L., S.F. Gray); pigweed, Amaranthus retroflexus (L.); kochia, Kochia scoparia (L. Schrad.); lambsquarters, Chenopodium album (L.); and field pepperweed, Lepidium campestre (L. R. Br.) into sterile soil, we compared two different watering regimes in two soil types to Petri plate germination of these seeds. Seed bank estimations from the emergence method were lower compared to estimations from the Petri plate germination. Top-and-bottom watering increased absolute abundance, and the rank order of abundance among species changed with watering method. Emergence levels were the same between the two soil types. The higher water availability of the top-and-bottom watering method resulted in greater seedling emergence $(26.3 \% \pm 10 \%$ SD vs. $9.1 \% \pm 7.5 \%$ SD). Lower emergence compared to germination $(62.3 \% \pm 24.4 \%)$ may indicate that emergence is an important postgermination barrier to seedling establishment. While emergence techniques may not accurately portray the volume of seeds in the soil, they may more accurately predict which plants can become established in field conditions. Our different species abundances between watering methods show that multiple emergence methods may need to be employed to forecast a range of future rangeland conditions from the soil seed bank.
\end{abstract}

\section{Resumen}

La evaluación de semillas viables en el suelo, también conocido como el reservorio o banco de semillas, es un componente crucial de muchos estudios de dinámica de malezas o de ecología vegetal. La estimación del banco de semillas se utiliza para predecir la posibilidad de futuras infestaciones de malezas, así como la diversidad de plantas nativas emergentes. Sin embargo no existe un método estandarizado de informar técnicas de evaluación de bancos de semillas, hecho que limita la habilidad de hacer comparaciones entre ensayos. Luego de sembrar cantidades conocidas de Bromus tectorum (L.), Vulpia bromoides (L., S.F. Gray), Amaranthus retroflexus (L.), Kochia scoparia (L. Schrad.), Chenopodium album (L.), y Lepidium campestre (L. R. Br.) en suelos estériles, comparamos dos regímenes de riego en dos suelos diferentes con la germinación de estas semillas en cápsulas de Petri. Las estimaciones de banco de semillas utilizando el método de emergencia fueron inferiores a las estimaciones de germinación de las cápsulas de Petri. La aplicación de riego superior e inferior produjo un incremento en la abundancia absoluta, y el orden de ranking de abundancia de especies varió con el sistema de riego aplicado. Los niveles de emergencia en los dos tipos de suelo fueron iguales. La disponibilidad de agua más elevada del sistema de riego superior e inferior produjo mayor emergencia de semillas $(26.3 \% \pm 10 \%$ DE vs. $9.1 \% \pm 7.5 \% \mathrm{DE})$. Los valores de emergencia inferiores a los de germinación $(62.3 \% \pm 24.4 \%)$ podrían indicar que la emergencia es una barrera post-germinación importante para el establecimiento de plántulas. Si bien las técnicas de emergencia posiblemente no reflejen de modo preciso el volumen de semillas en el suelo, podrían predecir con más precisión qué especies podrían establecerse en condiciones de campo. Las diferencias en abundancia de especies entre tratamientos de riego demuestran que múltiples métodos de emergencia podrían ser necesarios para pronosticar el rango de condiciones futuras de un pastizal a partir del banco de semillas.

Key Words: emergence, germination, seed bank methods, seed pool, weed seed bank

This project was funded in part by a grant under Public Law 109-103, Section 208(a), through the US Bureau of Reclamation (Cooperative Agreement 06FC204044).

At the time of the research, the first author was a postdoctoral scholar, Dept of Natural Resources, University of Nevada, Reno, Reno, NV 89557, USA.

Correspondence: Erin Espeland, USDA ARS NPARL, 1500 N Central Ave, Sidney, MT 59270, USA. Email: erin.espeland@ars.usda.gov

Manuscript received 29 July 2009; manuscript accepted 3 December 2009.

\section{INTRODUCTION}

The importance of viable buried seeds, or the seed bank, has been discussed in scientific literature since 1857 when it was noticed that disturbed soils could produce "odd floras" (Oosting and Humphreys 1940). Primary reasons for estimating seed banks include defining the flora of an area (Major and 
Pyott 1966), understanding both plant population and plant community dynamics (Hanson 1938; Houle 1998; Allen and Nowak 2008), and forecasting of weed infestations (Ball and Miller 1989; Creech et al. 2008). Seed bank assessment can illuminate seed inputs from the past that may not presently be apparent in aboveground vegetation because of climatic or competitive factors.

The debate regarding the proper method of estimating seed banks began as early as 1919 (Crocker 1919) and is still unresolved. While the "extraction method" of removing seeds from the soil and counting them might be the most accurate (Mesgaran et al. 2007), time, money, and personnel limitations result in the continuing use of "emergence methods" for assessing seed banks (Kalamees and Zobel 2002; Ris Lambers et al. 2005; Clarke and Dorji 2008). In this method, the soil sample is watered, and the emerged seedlings are identified and counted. While emergence methods are sometimes referred to as "germination methods" (Feast and Roberts 1973), they technically measure not seed germination but rather emergence. The emergence method may underestimate viable seed pools because some dormancies may not be broken within the experimental time frame (Guo et al. 1998). The extraction method, however, may be an overestimate (Cash et al. 1998; Guo et al. 1998) because not all counted seeds will be viable, although this can be corrected with tetrazolium testing for larger seeds. Both extraction and emergence methods may be poor predictors of standing weed densities in situ (Ball and Miller 1989).

The wide variety in documented seed bank emergence methods makes comparing across studies difficult. Differences between methods include length of time allowed for germination, sample pretreatment and preparation (e.g., freezing, wetting-drying cycle), temperature regime, and watering regime. The length of time allowed for emergence has ranged from weeks (Thompson and Grime 1979; Gross 1990; Clarke and Dorji 2008) to months (Oosting and Humphreys 1940; Champress and Morris 1948; Figueroa et al. 2004; IshkawaGoto and Tsuyuzaki 2004) to years (Chippendale and Milton 1934; Valbuena and Trabaud 2001). Sample preparation has also been variable, including spreading the soil in a container (Chippendale and Milton 1934; Oosting and Humphreys 1940), over sand (Champress and Morris 1948; Thompson and Grime 1979; Figueroa et al. 2004; Clarke and Dorji 2008), or over soilless seeding mixes and vermiculite (Gross 1990; Holmes and Cowling 1997; Kalamees and Zobel 2002; Ishkawa-Goto and Tsuyuzaki 2004; Ris Lambers et al. 2005). Consistent water availability is important, with greatest emergence occurring in continually moist soils (Weise and Davis 1967; TerHeerdt et al. 1999). Historically, watering rates or the direction of water application have not been completely described (Oosting and Humphreys 1940; Thompson and Grime 1979; Holmes and Cowling 1997; Cash et al. 1998). Comparative methodological studies are few, but quantitative results on the differences in germination and emergence among methods are extremely helpful (Ball and Miller 1989; IshkawaGoto and Tsuyuzaki 2004). These studies show that, depending on the species involved, extraction and emergence methods can give either very similar or very different pictures of the plant community within the seed bank. Thus, it is important to employ more than one seed bank estimation technique in order to observe a range of likely compositions of the seed bank.
In order to address the question of how watering methods and soil type may affect seed bank estimations using the emergence technique, we compared a top-watering method to a top-andbottom watering method. We performed both methods using known quantities of six weed species and used two soil types (loam and silt loam) with different water-holding capacities. We compare our emergence results with germination tests to examine how differences between germination and emergence in these six species affect estimation of soil seed banks.

\section{MATERIALS AND METHODS}

Two grass and four forb species were used in this experiment. Cheatgrass, Bromus tectorum (L.), and brome fescue, Vulpia bromoides (L., S. F. Gray), were field collected from sites near Reno, Nevada. To compare the performance of these annual grass seeds to those of weedy forb species, we purchased seeds of four additional species from Herbiseed (Twyford England, United Kingdom): pigweed, Amaranthus retroflexus (L.); kochia, Kochia scoparia (L. Schrad.); lambsquarters, Chenopodium album (L.); and field pepperweed, Lepidium campestre (L. R. Br.). Two field-collected soils were used in this experiment: Malpais gravelly loamy sand (loamy, skeletal, mixed, mesic, Typic Camborthids) collected near Yerington, Nevada, and Yolo silt loam (fine, silty, mixed, nonacid, thermic, Typic Xerothents) collected from the northern Central Valley of California. Loamy sands range from 10\% to $15 \%$ clay content, and the majority of the remainder is sand with a negligible amount of silt (US Department of Agriculture, Natural Resources Conservation Service [USDA, NRCS]). Silt loams range from $75 \%$ to $90 \%$ silt content, and the majority of the remainder is sand with a negligible amount of clay (USDA, NRCS). Soil was autoclaved to kill any remnant seeds. Soil and additional sand were mixed at a 2:1 ratio to prevent soil hardening while drying: $400 \mathrm{~mL}$ of each soil were mixed with $200 \mathrm{~mL}$ of sand for each $(25.4 \mathrm{~cm} \times 25.4 \mathrm{~cm})$ tray.

Soil was spread $0.5 \mathrm{~cm}$ thick in slightly perforated trays (standard nursery trays with drainage holes; Hummerts International) placed in a completely randomized design on glasshouse benches. The benches were covered with polyester quilt batting and the trays placed on top of the batting. The polyester allowed water to wick up through the bottom of the top-and-bottom watering trays. Top-only watering trays were placed inside another slightly perforated tray to prevent bottom-watering but to allow for drainage. Top-and-bottom watered trays consisted of a 1-cm layer of perlite topped with landscaping cloth, which prevented the soil on top of the cloth from mixing with the perlite. Each soil type and watering method had 10 replicates. Twenty-five seeds of each species were mixed into a randomly selected half of the soil of each tray. The other half of the tray was unsown so that subsequent sampling for water content would not remove any seeds.

Trays were misted from above for 10 min once per day (approximately $400 \mathrm{~mL}$ of tap water per tray per application) in cool weather (below $21^{\circ} \mathrm{C}$ ) and twice per day in warmer weather (above $21^{\circ} \mathrm{C}$ ). The quilt batting was soaked with a hose every other day. Glasshouse temperatures were bufferedambient, remaining above $7^{\circ} \mathrm{C}$ at night and below $26^{\circ} \mathrm{C}$ during the day. Emergence was checked once per week throughout 
Table 1. Germination percentages ( \pm SD) from Petri plate method, emergence percentages $( \pm S D$ ) for top-and-bottom and top-only watering methods, and ranked order of abundance for each species within each method.

\begin{tabular}{|c|c|c|c|c|}
\hline Species & Petri plate & Top-and-bottom & Top-only & Ranks $^{1}$ \\
\hline Cheatgrass & $97.5 \pm 1.9$ & $38.0 \pm 17.2$ & $22.4 \pm 17.9$ & $1,2,2$ \\
\hline Brome fescue & $81.5 \pm 6.2$ & $49.0 \pm 18.1$ & $23.0 \pm 25.0$ & $2,1,1$ \\
\hline Pigweed & $64.0 \pm 0.0$ & $26.6 \pm 19.2$ & $3.6 \pm 7.6$ & $3,3,3$ \\
\hline Field pepperweed ${ }^{2}$ & $54.0 \pm 9.1$ & $22.6 \pm 12.1$ & $2.0 \pm 4.2$ & $4,4,5$ \\
\hline Kochia & $53.5 \pm 5.7$ & $12.4 \pm 9.3$ & $0.6 \pm 2.0$ & $5,5,6$ \\
\hline Lambsquarters & $23.5 \pm 6.8$ & $9.0 \pm 7.0$ & $3.2 \pm 6.4$ & $6,6,4$ \\
\hline Mean across species & $62.3 \pm 24.4$ & $26.3 \pm 10.0$ & $9.1 \pm 7.5$ & \\
\hline
\end{tabular}

${ }^{1}$ Species rank in Petri plate method, top-only watering, and top-and-bottom watering method.

${ }^{2}$ Change in ranked abundance between emergence methods significant $(P<0.025)$ using the $z$ statistic (Table 3).

each wet cycle (cycles described below). After plants emerged and were identified, they were removed from the sample.

To determine soil water content over time, soil samples of $5 \mathrm{~g}$ were collected immediately after watering from each tray, every $2 \mathrm{~h}$ for $10 \mathrm{~h}$, and finally after $24 \mathrm{~h}$. The soil sampling was performed on a day where there was only one watering period. The samples were weighed at the time of collection and after $2 \mathrm{~d}$ of drying at $105^{\circ} \mathrm{C}$. Percent gravimetric water content ([g wet soil - g dry soil]/g wet soil) was calculated for each sample.

To break seed dormancy in a relatively short period of time, we embarked on a regime of wetting, drying, and mixing the soil over a period of 4 mo. The wet-dry regime included two wet cycles, one dry cycle, and a final wet cycle. Each cycle lasted approximately $30 \mathrm{~d}$. Samples were kept watered for $30 \mathrm{~d}$ (wet cycle number 1), and the soil was stirred and then watered for another $30 \mathrm{~d}$ (wet cycle number 2). The samples were then left to dry for $30 \mathrm{~d}$ (dry cycle), after which the soils were again stirred and watered for the final 30-d wet cycle.

A germination test of four replicates of 50 seeds of each species was prepared in Petri plates on filter paper (Whatman No. 1) and performed for the first $30 \mathrm{~d}$ of the emergence test. Filter paper was wet with distilled water, a lid was placed over the plate, and the container was sealed with parafilm. Plates were placed in a plastic-lined cardboard box inside the greenhouse to experience the same temperatures as the seeds in the emergence experiment. Plates were kept in the dark except when they were examined for germination. Germinated seeds were counted and removed from the plates once per week, and the filter paper was kept moist throughout the experiment. No wet-dry cycling or other dormancy-breaking treatment was applied to the seeds in this test.
Percent germination and emergence were analyzed using SPSS for Windows 17. To avoid problems inherent in modeling bounded (percentage) data, we used a nonparametric KruskalWallis $\mathrm{H}$ to determine differences among the seed bank estimation methods and soil types. The $z$ statistic determined the statistical significance of apparent changes in species ranks between emergence methods (Siegel and Castellan 1988). Gravimetric soil water content data were analyzed using repeated-measures multiple analysis of variance in JMP v. 7.1 for Mac OS X (SAS Institute, Cary, NC). We considered $P$ values less than 0.05 to be significant.

\section{RESULTS}

Germination percentages were higher than emergence percentages for all species (Tables 1 and 2). All species had significantly higher emergence fractions using the top-andbottom watering method compared with the top-only watering method (Tables 1 and 2). There was no significant difference in emergence found between the two soil types $(P>0.4$, data not shown). Most emergence occurred in the first month of the study, and dead seedlings were included in the data set.

Estimated species seed bank abundance differed by method. Cheatgrass had the highest germination $(97.5 \% \pm 1.9 \%)$ but only the second-highest emergence in the emergence methods $(38 \%$ and $22 \%)$. No other species changed its abundance rank when comparing the germination and top-and-bottom watering emergence method (Table 1). Abundances for half the species appeared to differ between the two watering methods (Table 1). The change in abundance rank of field pepperweed

Table 2. Statistical summary of Kruskal-Wallis tests.

\begin{tabular}{|c|c|c|c|c|c|c|}
\hline \multirow[b]{2}{*}{ Species } & \multicolumn{3}{|c|}{ Germination vs. emergence } & \multicolumn{3}{|c|}{ Top-only vs. top-and-bottom } \\
\hline & Chi-square & $d f$ & $P$ value & Chi-square & $d f$ & $P$ value \\
\hline Cheatgrass & 10.76 & 1 & 0.001 & 6.75 & 1 & 0.009 \\
\hline Brome fescue & 9.16 & 1 & 0.002 & 11.95 & 1 & 0.001 \\
\hline Pigweed & 9.99 & 1 & 0.002 & 22.07 & 1 & $<0.0001$ \\
\hline Lambsquarters & 9.40 & 1 & 0.002 & 10.53 & 1 & 0.001 \\
\hline Kochia & 11.81 & 1 & 0.001 & 24.71 & 1 & $<0.0001$ \\
\hline Field pepperweed & 10.84 & 1 & 0.001 & 25.48 & 1 & $<0.0001$ \\
\hline All species & 10.68 & 1 & 0.001 & 21.30 & 1 & $<0.0001$ \\
\hline Soil & - & - & - & 0.70 & 1 & 0.401 \\
\hline
\end{tabular}


Table 3. Summary of $z$ statistic test of abundance rank differences in lambsquarters, kochia, and field pepperweed between emergence methods; other species not tested because they did not change ranks among methods.

\begin{tabular}{lccl}
\hline \multicolumn{1}{c}{ Species } & Rank difference & df & $P$ value \\
\hline Lambsquarters & 1.45 & 1 & $>0.1$ \\
Kochia & 2.95 & 1 & $>0.1$ \\
Field pepperweed & 5.15 & 1 & $<0.025$ \\
\hline
\end{tabular}

was significant $(P<0.025)$, while the changes in abundance rank for lambsquarters and kochia was not significant $(P>0.1$; Table 3).

The two watering methods differed in soil moisture dynamics. Soil in the top-only watering method quickly dried in the 24-h period after watering, while water availability in the top-and-bottom watering method was more consistent (time $\times$ method interaction; Table 4; Fig. 1). Soil water content differed between soil types, with the silt loam $(22.9 \% \pm 9.1 \%)$ possessing a greater water-holding capacity than the sandy loam $(16.2 \% \pm 9.1 \%$; Table 4$)$. Each soil dried at the same rate, however (Fig. 1; soil $\times$ time interaction was not significant, $P>0.8$; Table 4$)$.

\section{DISCUSSION}

Soil type did not influence total emergence or change in water availability over time under either watering method, indicating that these methods are robust to some variability in soil texture and water content. The top-and-bottom watering method showed higher emergence for all six weed species, and this success is likely due to consistently high water availability within the trays. However, emergence percentages from the soil were much lower than germination percentages observed in Petri plates. Thus, emergence does not reflect the absolute abundance of germinable seed in the soil.

Even though our germination percentages were high, they may have been higher if we had applied some dormancybreaking treatment, such as freezing, to these seeds. The two grasses we used in this study have nonspecific germination requirements, while many weedy forb species have strong dormancy (Hock et al. 2006), and the form and strength of this dormancy can vary by population source and maternal environment (Clauss and Venable 2000). While seeds in the emergence method were watered longer and experienced dormancy-breaking wet-dry cycles, these factors did not add significantly to the emergence recorded: the majority of plants emerged in the first month. The germination trial in the Petri plates had no dormancy-breaking treatment applied, yet the germination rates were high.

The difference between germination and emergence is one that is not well appreciated, perhaps because the life history stage between these two events is difficult to measure. Our different results for emergence and germination under the same glasshouse and temperature regime indicates that either 1) emergence is a significant postgermination barrier to plant establishment or 2) germination rates are lower in soil compared with on filter paper. The time step between
Table 4. Results of repeated-measures multiple analysis of variance showing the effect of soil and watering treatment on gravimetric soil water content. Between-subject analysis compares main treatments and interactions, and within-subject analysis compares how these treatments and interactions change over time. Degrees of freedom are indicated as numerator, denominator.

\begin{tabular}{lrrr}
\hline \multicolumn{1}{c}{ Test } & \multicolumn{1}{c}{$F$} & df & $P$ value \\
\hline Between subject & & & \\
$\quad$ Overall model significance & 24.2 & 3,35 & $<0.0001$ \\
Soil & 28.8 & 1,35 & $<0.0001$ \\
Method & 40.9 & 1,35 & $<0.0001$ \\
Soil $\times$ method & 0.9 & 1,35 & 0.3407 \\
Within subject & & & \\
Overall model significance & 3.8 & 18,85 & $<0.0001$ \\
Time & 46.5 & 6,30 & $<0.0001$ \\
Time $\times$ soil & 0.5 & 6,30 & 0.8374 \\
Time $\times$ method & 12.9 & 6,30 & $<0.0001$ \\
Time $\times$ soil $\times$ method & 1.8 & 6,30 & 0.1256 \\
\hline
\end{tabular}

germination and emergence is one where microfauna and fungi can cause mortality, or seeds may not have the resources to push their cotyledons above the soil surface. However, germination in soil may also be lower than on filter paper, as the same microfauna and fungi that can destroy developing seedlings can also inhibit germination (Baskin and Baskin 1998). While emergence methods may not predict the amount of viable seed in the seed bank, they may more accurately portray the species that achieve the emergence stage in situ.

\section{IMPLICATIONS}

Absolute abundance of all species was significantly different among the three techniques in this study. Our results support the findings of Ishkawa-Goto and Tsuyuzaki (2004), who recommend that multiple methods be used to fully describe the range of possible rangeland conditions that the soil seed bank may predict. It is our hope that the results presented here will encourage researchers to thoroughly describe their seed bank

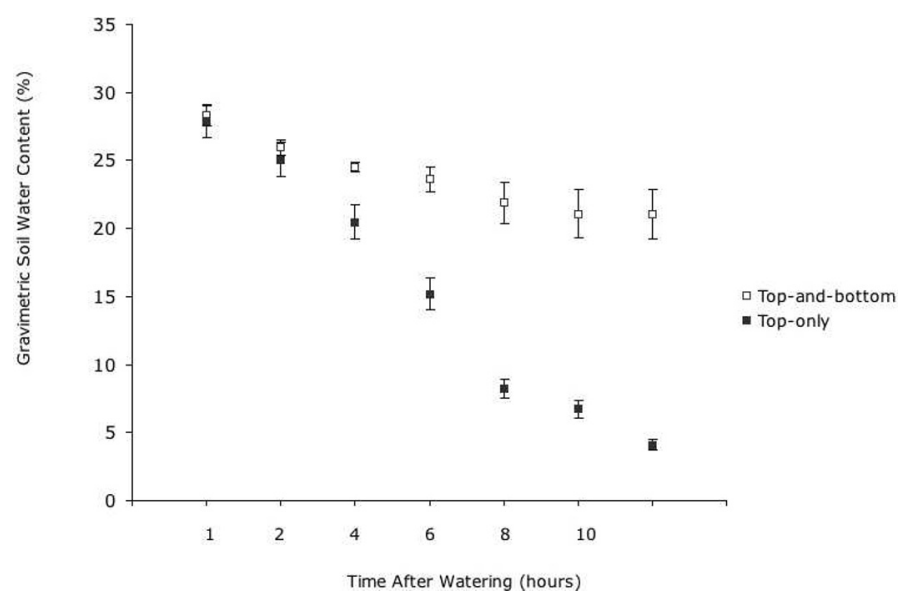

Figure 1. Time series of gravimetric water content by watering method. Bars are one standard error. 
estimation methodologies, including watering treatment, soil texture, soil preparation, soil water-holding capacity, and dormancy-breaking treatments. Simple statements about the timing of emergence would also be helpful to compare studies of different length. Because no seed bank estimation technique is without limitations, researchers must match the technique to the question at hand. While an extraction method followed by a germination test might be the most complete available description of the abundance of viable seeds in the soil, using multiple emergence methods within the same study may give useful information on possible relative emergence potential of common species in the soil under different, realistic climatic environmental conditions. That emergence methods result in a different species composition than what is observed in the landscape need not be a criticism of the technique when multiple methods are used. Instead, the difference between species emerging from the soil under multiple, controlled ex situ conditions and species abundance in the landscape may generate hypotheses regarding important ecological processes at work in rangeland systems.

\section{ACKNOWLEDGMENTS}

R. E. Creech provided us with an introduction to the top-and-bottom watering method. We thank A. Endo, H. Zamma, and L. Schmelzer for greenhouse assistance.

\section{LITERATURE CITED}

Allen, E. A., And R. S. Nowak. 2008. Effect of pinyon-juniper tree cover on the soil seed bank. Rangeland Ecology \& Management 61:63-73.

Ball, D. A., And S. D. Miller. 1989. A comparison of techniques for estimation of arable soil seedbanks and their relationship to weed flora. Weed Research 29:365-373.

BASKIN, C. C., AND J. M. BASKIN. 1998. Seeds: ecology, biogeography, and evolution of dormancy and germination. San Diego, CA, USA: Academic Press. $666 \mathrm{p}$.

Cash, S. D., D. L. Zamora, and A. W. Lenssen. 1998. Viability of weed seeds in feed pellet processing. Journal of Range Management 51:181-185.

Champress, S. S., and K. Morris. 1948. The population of buried viable seeds in relation to contrasting pasture and soil types. Journal of Ecology 36:149-173.

Chippendale, H. G., and W. E. J. Milton. 1934. On the viable seeds present in the soil beneath pastures. Journal of Ecology 34:508-531.

Clarke, P. J., ANd K. DoRJI. 2008. Are trade-offs in plant resprouting manifested in community seed banks? Ecology 89:1850-1858.

Clauss, M. J., and D. L. Venable. 2000. Seed germination in desert annuals: an empirical test of adaptive bet hedging. American Naturalist 155:168-186.

Creech, J. E., A. Westphal, V. R. Ferris, J. Faghini, T. J. Vyn, J. B. Santini, and W. G. JoHnson. 2008. Influence of winter annual weed management and crop rotation on soybean cyst nematode (Heterodera glycines) and winter annual weeds. Weed Science 56:103-111.

Crocker, W. 1919. Buried weed seeds. Botanical Gazette 67:515-516.

FEASt, P. M., AND H. A. Roberts. 1973. Note on the estimation of viable weed seeds in soil samples. Weed Research 13:110-113.

Figueroa, J. A., S. TeILlier, and F. M. Jaksic. 2004. Composition, size and dynamics of the seed bank in a Mediterranean shrubland of Chile. Austral Ecology 29:574-584.

Gross, K. L. 1990. A comparison of methods for estimating seed numbers in the soil. Journal of Ecology 78:1079-1093.

Guo, Q. F., P. W. Rundel, and D. W. Goodall. 1998. Horizontal and vertical distribution of desert seed banks: patterns, causes, and implications. Journal of Arid Environments 38:465-478.

Hanson, H. C. 1938. Ecology of the grassland. The Botanical Review 4:51-82.

Hock, S. M., S. Z. Knezevic, C. L. Petersen, J. Eastin, and A. R. Martin. 2006. Germination techniques for common lambsquarters (Chenopodium album) and Pennsylvania smartweed (Polygonum pensylvanicum). Weed Technology 20:530-534.

Holmes, P. M., AND R. M. Cowling. 1997. Diversity, composition and guild structure relationships between soil-stored seed banks and mature vegetation in alien plant-invaded South African Fynbos shrublands. Plant Ecology 133:107-122.

Houle, G. 1998. Seed dispersal and seedling recruitment of Betula alleghaniensis: spatial inconsistency in time. Ecology 79:807-818.

IsHIKAWA-Goto, M., AND S. TsuYUZAKI. 2004. Methods of estimating seed banks with reference to long-term seed burial. Journal of Plant Research 117:245-248.

Kalamees, R., and M. Zobel. 2002. The role of the seed bank in gap regeneration in a calcareous grassland community. Ecology 83:1017-1025.

MajoR, J., AND W. T. Pyott. 1966. Buried, viable seeds in two California bunchgrass sites and their bearing on the definition of a flora. Vegetatio 13:253-282.

Mesgaran, M. B., H. R. Mashhadi, and H. M. Alizadeh. 2007. Comparison of three methodologies for efficient seed extraction in studies of soil weed seedbanks. Weed Research 47:472-478.

Oosting, H. J., And M. E. Humphreys. 1940. Buried viable seeds in a successional series of old field and forest soils. Bulletin of the Torrey Botanical Club 67:253-273.

Ris Lambers, J. H., J. S. ClaRk, And M. Lavine. 2005. Implications of seed banking for recruitment of southern Appalachian woody species. Ecology 86:85-95.

Siegel, S., and N. J. Castellan, JR. 1988. Nonparametric statistics for the behavioral sciences. 2nd ed. New York, NY, USA: McGraw-Hill. 399 p.

Terheerdt, G. N. J., A. Shutter, And J. P. Bakker. 1999. The effect of water supply on seed-bank analysis using the seedling-emergence method. Functional Ecology 13:428-430.

Thompson, K., and J. P. Grime. 1979. Seasonal-variation in the seed banks of herbaceous species in 10 contrasting habitats. Journal of Ecology 67:893-921.

[USDA, nRCS] us Department of Agriculture, Natural Resources Conservation Service. National soil survey handbook, title 430-VI, exhibit 618-9. Available at: http://soils.usda.gov/technical/handbook. Accessed 19 November 2009.

Valbuena, L., and L. Trabaud. 2001. Contribution of the soil seed bank to post-fire recovery of a heathland. Plant Ecology 152:175-183.

Weise, A. F., and R. G. Davis. 1967. Weed emergence from two soils at various moistures, temperatures, and depths. Weeds 15:118-121. 